Article

\title{
Feasibility of Coupling PS System with Building Protection in an Ultrasoft Strata Colliery
}

\author{
Song Guo ${ }^{1,2}$, Guangli Guo ${ }^{1,2, *}$, Xiangsheng Yang ${ }^{1,2}$ and Qiu Du ${ }^{1,2}$ \\ 1 Jiangsu Key Laboratory of Resources and Environment Information Engineering, \\ China University of Mining and Technology, Xuzhou 221116, China; guosong@cumt.edu.cn (S.G.); \\ yangxs@cumt.edu.cn (X.Y.); duqiucumt@163.com (Q.D.) \\ 2 School of Environment Science and Spatial Informatics, China University of Mining and Technology, \\ Xuzhou 221116, China \\ * Correspondence: glguo1965@163.com; Tel.: +86-13615104142
}

check for updates

Citation: Guo, S.; Guo, G.; Yang, X.; $\mathrm{Du}, \mathrm{Q}$. Feasibility of Coupling PS System with Building Protection in an Ultrasoft Strata Colliery. Sustainability 2021, 13, 1015. https://doi.org/ $10.3390 /$ su13031015

Received: 28 December 2020

Accepted: 17 January 2021

Published: 20 January 2021

Publisher's Note: MDPI stays neutral with regard to jurisdictional claims in published maps and institutional affiliations.

Copyright: (c) 2021 by the authors. Licensee MDPI, Basel, Switzerland. This article is an open access article distributed under the terms and conditions of the Creative Commons Attribution (CC BY) license (https:// creativecommons.org/licenses/by/ $4.0 /$ )

\begin{abstract}
To guarantee the stability of a building complex above a planned mining district with ultrasoft strata, strip mining technology (SMT) was applied to control the displacement and deformation caused by underground exploitation. This study attempts to design a reasonable pillar width to establish a stable pillar-support (PS) system composed of ground buildings with coal pillars underneath. Based on the stratigraphic structure of ultrasoft strata and in situ measurement data of mining subsidence monitoring, this study takes an ultrasoft strata colliery in western Henan province, central China, as an example to examine the technical and economical feasibility of the proposed PSsyst under two mining scenarios. The major results indicated that the initial design of pillar width would be $120 \mathrm{~m}$ under scenario 1, with expected damage of only $450 \mathrm{~mm}$ maximum subsidence predicted by probability integration method (PIM); while under scenario 2, the cost of compensation for buildings' mining-induced damage would increase to CNY 61.31 million with an expected output of 7.629 million tons of raw coal. Moreover, the protection rate of the residential area in the proposed postmining area of scenario 1 can reach as much as $6.91 \%$ comparing to the fully mechanized coal winning technology in scenario 2. Overall, the proposed PSsyst will bring good benefits both economically and environmentally and should be worth promoting as a reference for similar geological and mining conditions in the future.
\end{abstract}

Keywords: strip mining technology; pillar-support system; probability integration method; economic benefit

\section{Introduction}

The ground subsidence caused by underground exploitation is the primary cause of deformation and damage to building complexes. To alleviate irreversible mining-induced disasters, strip mining technology (SMT) is one of the green mining approaches that could realize the collaboration between sustainable mining of coal resources and deformation control of ground building complexes [1-5]. Some studies mainly focused on the technical equipment and mining process of SMT [6-8], or have presented a set of methodologies to assess the potential of pillar-support (PS) systems under conventional geological and mining conditions [9]. Dating back to the 1950s, Poland, the former Soviet Union, France, and other coal mining countries began to apply SMT to realize the synergy of underground coal resources exploitation while protecting the ground buildings or structures from mining-induced damage [10,11]. Poland applied this technique in Katowice, Bertom, and other cities, with a resource recovery rate of about $45.8 \sim 60.0 \%$, surface subsidence coefficient generally less than 0.1 , even within deep mining, and a subsidence coefficient of only 0.16 [12]. SMT began to be applied in China during the 1960s following extensive applications in several coal mines such as Xuzhou, Fengfeng, Handan, Yanzhou, Jibei, etc. [13]. The principle of a conventional SMT is shown in Figure 1. The mining district 
was divided into a regular strip shape and mining one strip panel, with one strip pillar to support the overburden load. After the whole district mining strip panels were exploited, the surface formed a single slight subsidence basin. In general, the mining depth was less than $500 \mathrm{~m}$, the mining thickness was below $6 \mathrm{~m}$, the recovery rate was between $40 \%$ and $68 \%$, the panel recovery rate was between $30 \%$ and $60 \%$, and the surface subsidence coefficient was generally less than 0.2 [14]. With SMT rapidly being developed in China, this technique makes it possible to significantly reduce the severe contradictions between coal exploitation and environmental protection and realize sustainable development, which is reflected in the process of development and protection. SMT is used to achieve the dual goals of economic benefit and ground subsidence control, and reflects the fundamental idea of giving priority to the environment and maintaining development in China. $[15,16]$.

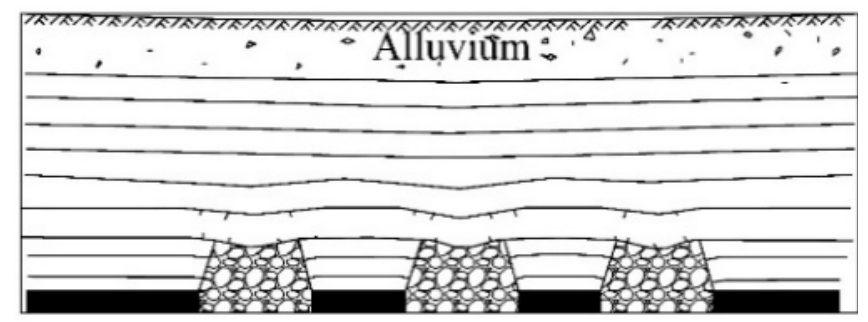

Figure 1. Principle of strip mining technology.

The accurate designation of coal pillar width has significantly affected the long-term stability of buildings above the planned mining district. Nevertheless, the original rock stress of overlying strata in goaf was changed by underground exploitation; the comprehensive analysis between fractured rock mass and mining-induced surface subsidence is the crucial issue to control the displacement and deformation of building complexes reasonably. Many scholars have put forward diverse methodologies to assess the stability of the project site-for example, numerical simulation analysis [17-19], similar-material simulating physical experiments [20], three-directional force analysis [21], long time-series ground deformation monitoring [22], mechanical-statistic coupling analysis [23,24], comparative analysis of different mining technologies, etc. [25,26].

Apart from these, the coal reserves of the ultrasoft stratigraphic structures ("three-soft" with ultrasoft roof, ultrasoft coal seam, and ultrasoft coal floor) account for a considerable proportion of the total coal reserves in China [27]. It is difficult to extract the ultrasoft coal seam accompanied by the control of the strata roof and floor and the high accident rate of coal extraction. Therefore, more attention has been paid to the problem of reasonable mining of ultrasoft coal seam from very early on in the use of this method. Some studies conducted the certainty model on ultrasoft strata, which was established by using geological and mining variables, applying the mechanical properties of the strata as a physical interpretation, and a large amount of time-series in situ monitoring data were obtained by Network Continuously Operating Reference Stations (CORS) and high-precision leveling as a statistical examination to establish the hybrid model. It is an effective way to reveal the mining subsidence regularity of ground buildings caused by underground exploitation through the mechanics-statistics approach, which has the "posterior" feature [28,29].

Overall, this study conducted a technical and economic feasibility study of SMT-PSsyst based on the mechanics-statistics approach aims to extract ultrasoft coal seam. It reveals the ground displacement and deformation regularity by coupling the ground deformation monitoring data to optimal parameter inversion with the probability integration method (PIM) to predict the surface displacement and deformation underneath the building complex in the planned mining district. It has important engineering significance and practical value for solving the problem of stability evaluations of the buildings and structures caused by underground extraction. 


\section{Methodology and Materials}

This research aims to evaluate the technical and economic feasibility of the building protection above the proposed mining areas synergy via the PSsyst, used to simulate the operation of mining subsidence and for cost-benefit analysis.

\subsection{Stability Influence Factors of PSsyst}

The essential surface displacement and deformation are synergistically affected by the dynamical system consisting of a goaf roof, coal pillar, and goaf floor. The basic form of rock strata and surface deformation at first extraction is mainly the bending of rock strata above the mining panels and the compression of coal pillars. Under the coupling of a long-term effect of the overburden and the coal pillar creep under the influence of underground water and seismic force [30,31], the coal pillar may cause rheology easily, leading to the "activation". In a stable PSsyst of SMT as shown in Figure 2a, each pillar in the system acts as a bridge pier to support the overlying rock mass. Then, the edge begins to yield and collapse, leading to a decrease in the effective bearing area (namely the core area of the coal pillar). When reduced to a certain extent, paroxysmal instability may occur (Figure 2b), which in turn causes the instability of adjacent coal pillars (Figure 2c) and leads to the chain activation of the whole PSsyst (Figure 2d).

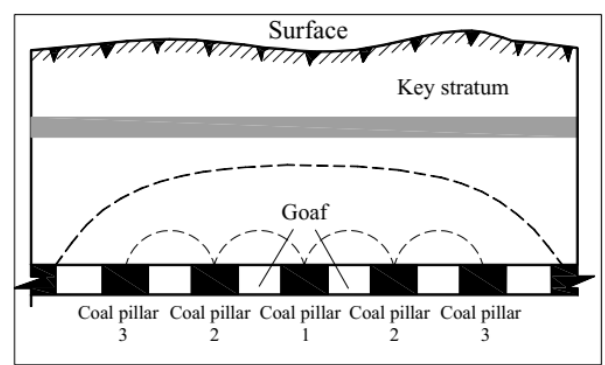

(a) Stable strip pillar system

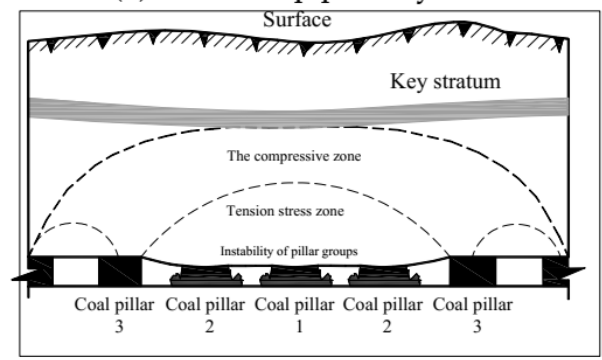

(c) Instability of adjacent pillar

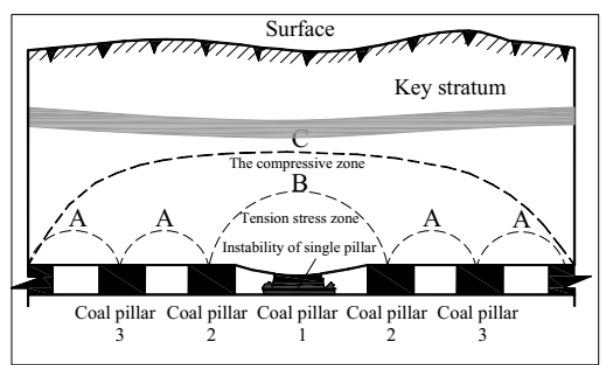

(b) Instability of single pillar

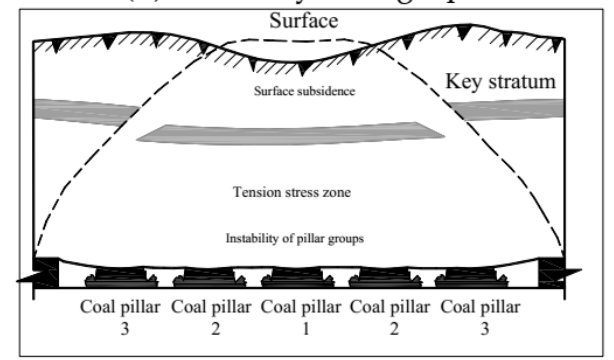

(d) Strip pillar instability in goaf

Figure 2. Sketch map of dynamic stability of PSsyst.

Therefore, the significant influence factor to evaluate the stability of PSsyst to ensure the safety of the above building complex is pressure safety indicator $K_{\mathrm{c}}$. According to the coal pillar stability theory [32], if the overburden load supported by the coal pillar reaches the limit, the bearing capacity of the PSsyst decreases to zero, and the coal pillar will be destroyed. Generally, the $K_{c}$ is calculated by the following (Formula (1)):

$$
K_{c}=\frac{F_{j}}{N_{s}}
$$

where $F_{j}$ is the ultimate limit capacity of coal pillar, $\mathrm{kN} ; N_{S}$ is the actual load value of the coal pillar in SMT, kN. For strip pillars with much greater lengths than widths, the ultimate limit capacity $F_{j}$ is calculated as follows (Equation (2)):

$$
F_{j}=40 \rho g H\left(a-4.92 m H \times 10^{-3}\right)
$$


where $\rho$ is the average density of the overlying strata, $\mathrm{t} / \mathrm{m}^{3} ; H$ is the mining depth, $\mathrm{m} ; a$ is the width of the coal pillar, $\mathrm{m}$. The actual load $N_{s}$ borne by the strip pillar is calculated by the following formula:

$$
N_{s}=10 \rho g(H a+b / 2(2 H+b / 0.6))
$$

where $b$ is the mining width of the strip, m. According to the above coal pillar stability analysis, then:

$$
K_{c}=\frac{F_{j}}{N_{s}}=\frac{40 \rho g H\left(a-4.92 m H \times 10^{-3}\right)}{10 \rho g(H a+b / 2(2 H+b / 0.6))}
$$

Under the three-direction stress state, the $K_{c}=1.5 \sim 2.0$ can guarantee the long-term support stability of the PSsyst [33,34].

\subsection{Probability Integration Method}

The probability integration method (PIM), based on stochastic medium theory [35,36], is extensively used in mining subsidence predictions in China. Its prediction parameters include the following: subsidence coefficient $q$, displacement factor $b$, the tangent of major influence angle $\tan \beta$, deviation of inflection point $s$, and propagation angle of extraction $\theta$. The formula of arbitrary point PIM mining of subsidence $A(x, y)$ is given as follows (Equations (5)-(7)):

$$
\begin{gathered}
W(x, y)=W_{c m} C^{\prime}{ }_{x} C^{\prime}{ }_{y} \\
C^{\prime}{ }_{x}=\frac{1}{\sqrt{\pi}}\left(\int_{0}^{\frac{x \sqrt{\pi}}{r}} e^{-\lambda^{2}} \cdot d \lambda-\int_{0}^{\frac{(x-L) \sqrt{\pi}}{r}} e^{-\lambda^{2}} \cdot d \lambda\right) \\
C^{\prime}{ }_{y}=\frac{1}{\sqrt{\pi}}\left(\int_{0}^{\frac{y \sqrt{\pi}}{r}} e^{-\lambda^{2}} \cdot d \lambda-\int_{0}^{\frac{(y-L) \sqrt{\pi}}{r}} e^{-\lambda^{2}} \cdot d \lambda\right)
\end{gathered}
$$

where $W_{c m}$ is the maximum surface subsidence under full subsidence conditions, $W_{c m}=m q \cos \alpha ; m$ is the mining thickness, $\mathrm{m} ; \alpha$ is the dip angle of coal seam; $C_{x}{ }^{\prime}, C_{y}{ }^{\prime}$ is the subsidence distribution coefficient of the projected point on the main section of the strike and inclined direction; $r$ is the main impact radius, $r=H / \tan \beta ; l$ and $L$ are panel strike length and inclined length; $x, y$ are the coordinates of the points to be solved. The flow chart and steps by using the PIM in PSsyst are shown in Figure 3.

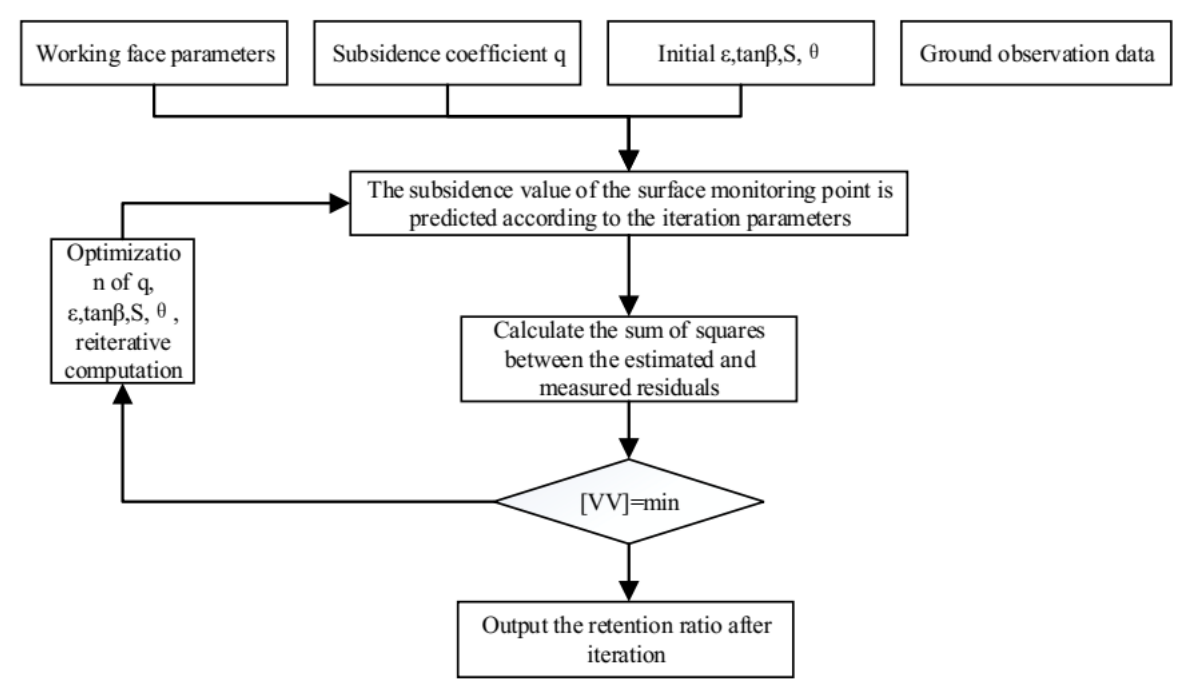

Figure 3. Flow chart of probability integration method (PIM) in PSsyst. 


\subsection{Data Description}

\subsubsection{The Observation Station in Panel 1208}

To determine the optimal pillar width for ultrasoft coal mining in the colliery, an observing station was built for dynamic monitoring to obtain mining subsidence data and mechanical parameters of rock strata in panel 1208. The observing station adopts Network CORS coupled with high-precision electronic leveling, and the monitoring data were selected for statistical modeling. Let the length of the surveying line along the strike direction of the coal seam be $X$, along the inclined direction be $Y$, and the mining depth of the coal seam be $Z$. Then, the model size satisfying the boundary conditions is shown in Figure 4 .

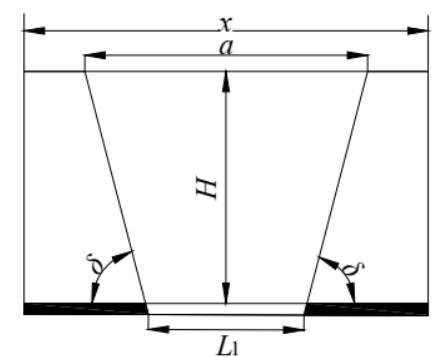

(a) Strike direction

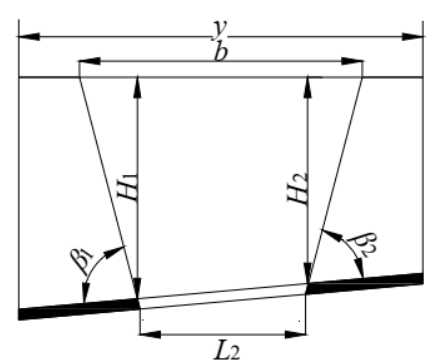

(b) Inclined direction

Figure 4. Surveying line of observing station.

Inclined direction surveying line should be consistent with the size of Equation (8):

$$
\mathrm{Y}>\mathrm{b}=L_{2}+H_{1} \cot \beta_{1}+H_{2} \cot \beta_{2}
$$

The size of the strike direction surveying line should conform to Equation (9):

$$
x>a=L_{1}+2 H \cot \delta
$$

where $a$ is the strike length surface displacement range; $b$ is the inclined length surface displacement range; $L_{1}, L_{2}$ are the strike and inclined length of goaf, respectively; $H$ is the mining depth; $\delta$ is the striking surface displacement angle; $\beta_{1}, \beta_{2}$ are the displacement angles of rising and dip, respectively.

With the above layout of the observing station, a long-term observing surveying line has been established and monitored in panel 1208 adjacent to the study area. The surveying line was simplified, as shown in Figure 5.

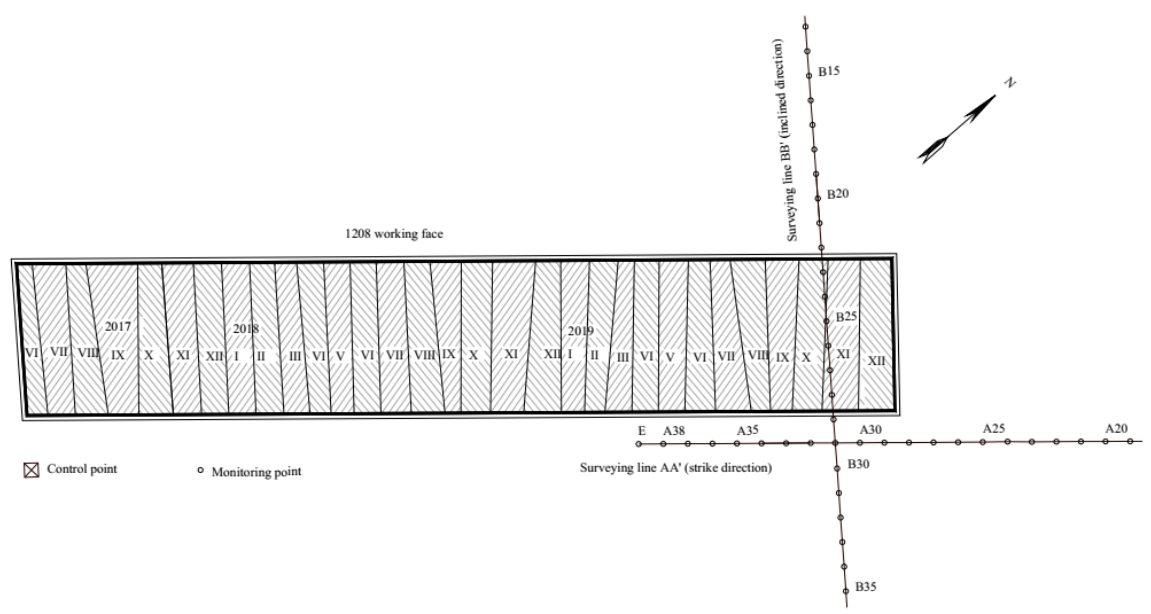

Figure 5. Survey line of panel 1208. 
The observing station was established in June 2017 when panel 1208 started to mine, and the time-series monitoring data of surface subsidence were collected from June 2017 to December 2019 until the panel stop mining. AA' represents the surveying line in strike direction, with 59 monitoring points and 4 control points; $\mathrm{BB}^{\prime}$ represents the surveying line in the inclined direction, and 40 monitoring points and 4 control points were assigned.

\subsubsection{Data Analysis}

After once-a-month monitoring of the area for a total of six times, the calculation was performed from the initial equilibrium state of the underground mining to the panel closed, and the displacement and subsidence in the strike and inclined directions are shown in Figure $6 a, b$, respectively.

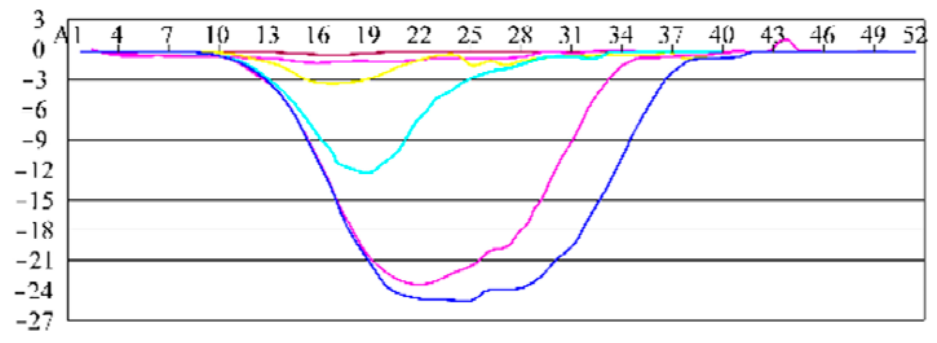

(a) Subsidence of the strike surveying line

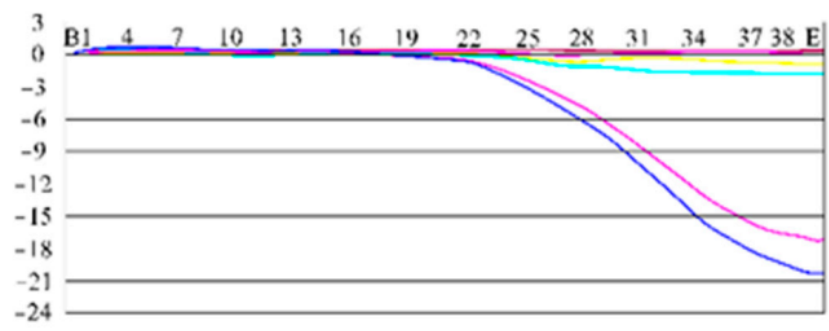

(b) Subsidence of the inclined surveying line

Figure 6. Subsidence monitoring curves.

With the influence of coal mining, the ground geomorphologic changed. It formed a subsidence basin much larger than the underground mining goaf. The maximum subsidence of panel 1208, which was located in the center of the working face goaf, was 0.026 $\mathrm{m}$. The subsidence takes the center of the goaf as the center, and the collapsed basin is elliptically distributed. The long axis of the ellipse is along the working face strikes. The largest subsidence is located in the center of the subsidence basin and decreases gradually on both sides of the goaf. As shown in Figure 6b, the exploitation of the underground coal seams has formed a surface collapse basin. Due to the different depths of the basin, the horizontal surface has different tensile and compressions, and the movement of each monitoring point would also be different. Therefore, the horizontal displacement of the surface also reflects the intensity of the surface displacement and deformation. The surface monitoring point on the main inclined section hardly produces the horizontal displacement perpendicular to the section. The horizontal displacement is positive in the upward direction. So, the inclined displacement is always toward the center of the working face goaf. Full subsidence under geological and mining conditions has not yet been achieved.

\subsection{Overview of Building Complex}

The planned working face panels of building complex above mainly consist of Zhang village, South and North Getiaogou Village, and No. 1 middle school of Shaan County. The recoverable reserves of raw coal beneath the building complex make up 6.246 million tons, accounting for $68.6 \%$ of the reserves of the whole coalfield in the colliery. The surface building distribution in the study area is shown in Figure 7.

Based on the field investigation and survey, the buildings are mainly brick and concrete 2-story bungalows, with a few brick and wood structures. The No.1 middle school of Shaan County has $4 \sim 6$ stories dormitories, which are mainly reinforced concrete structures. Satellite images of buildings are shown in Figure $8 \mathrm{a}-\mathrm{d}$, and photos of typical building structures are shown in Figure 8e-f. The total area of the building complex is $198,718 \mathrm{~m}^{2}$. The areas of Zhang village, North and South Getiaogou Village, and No.1 middle school of Shaan county are $95,031 \mathrm{~m}^{2}, 14,560 \mathrm{~m}^{2}, 36,937 \mathrm{~m}^{2}$, and $52,190 \mathrm{~m}^{2}$, respectively. 


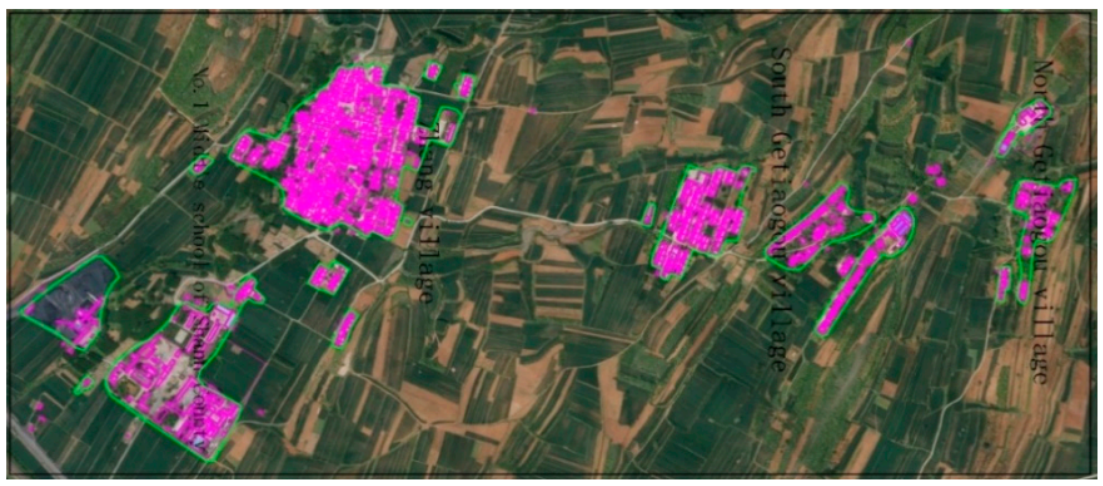

Figure 7. The surface building distribution in the study area.

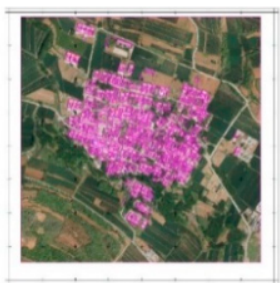

(a) Zhang Village

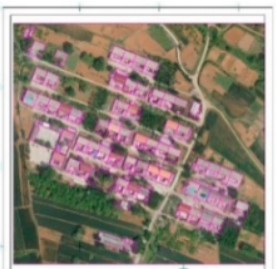

(b) South Getiaogou Village

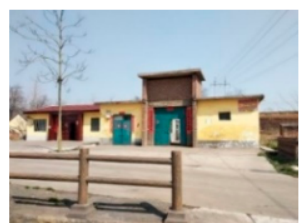

(e) Bungalow in Zhang Village

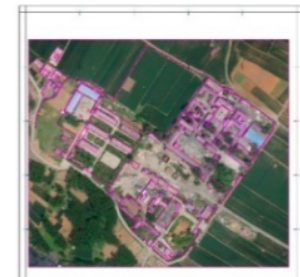

(c) No. 1 middle school of Shaan county

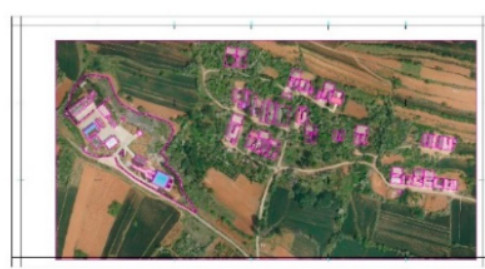

(d) North Getiaogou Village

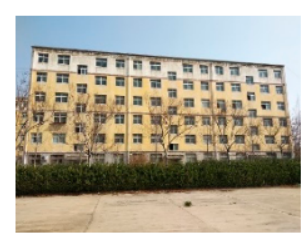

(f) Dormitory of the school in Shaan county

Figure 8. Photos of building in the study area.

\subsection{Scenario Design}

To accurately determine the area for buildings' protection, the pillar width of PSsyst was calculated. Based on the mechanical properties of the ultrasoft coal and rock strata determined by the laboratory experiment and in situ time-series monitoring data, the width of the PSsyst was designed to be $120 \mathrm{~m}$ and mining widths to be 90 and $170 \mathrm{~m}$, respectively. Two scenarios are considered in this study.

Scenario 1: The study area is divided into two sections for strip mining design and the arrange inclined section pillar width is $120 \mathrm{~m}$, for each section, to arrange a strip mining panel based on the alternate arrangement principle to carry out the design. The panel layout of SMT in the study area is shown in Figure 9.

The main technical parameters of each panel in scenario 1 are shown in Table 1.

Scenario 2: The fully mechanized coal winning panels are arranged in an approximate layout with mining strike widths of $170 \mathrm{~m}$, as shown in Figure 10. There are 8 mining panels in the whole mining district. All working faces adopt the single strike longwall backward coal mining method, fully mechanized coal mining technology of full-thickness coal mining at one time, and all caving methods to control the roof. 


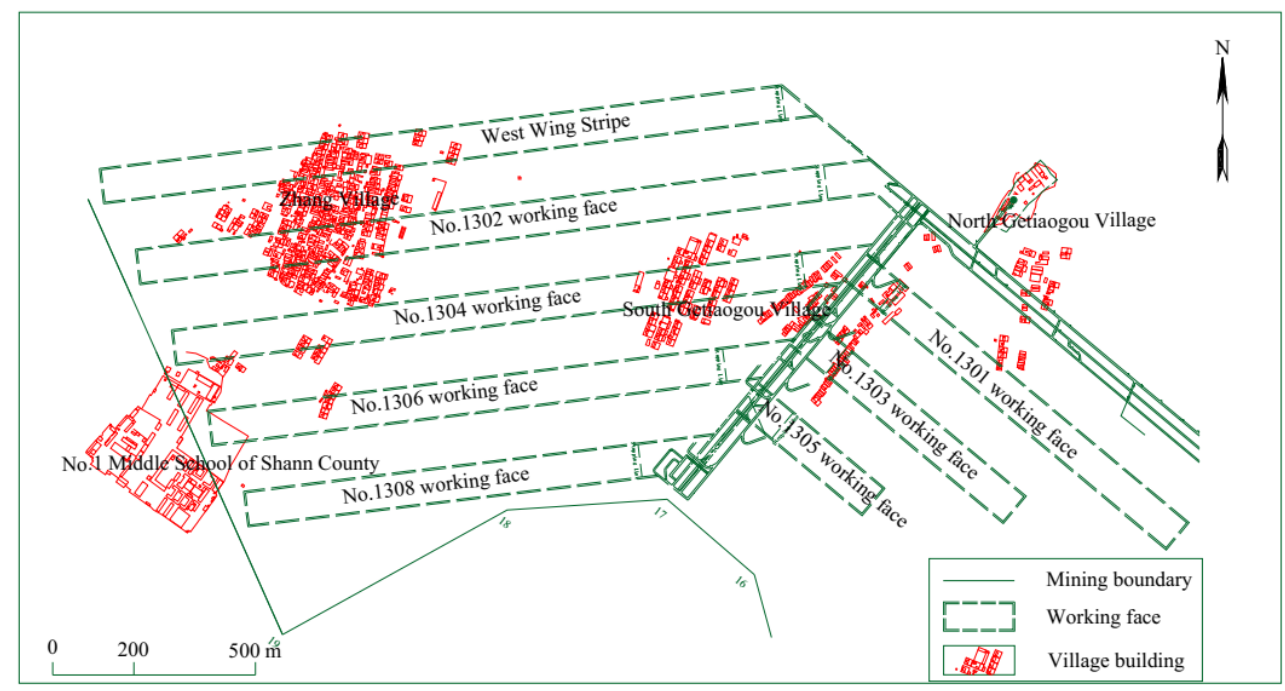

Figure 9. Panels layout of scenario 1 in the study area.

Table 1. Main technical parameters of each working face in scenario 1.

\begin{tabular}{|c|c|c|c|c|c|c|c|}
\hline Panels & $\underset{(\mathrm{m})}{\text { Mining Depth }}$ & $\begin{array}{l}\text { The Average } \\
\text { Mining Thickness } \\
(\mathrm{m})\end{array}$ & $\begin{array}{l}\text { Panel Length } \\
\text { (m) }\end{array}$ & $\begin{array}{l}\text { Panel Width } \\
\text { (m) }\end{array}$ & $\begin{array}{c}\text { Pillar Width } \\
\text { (m) }\end{array}$ & $\begin{array}{l}\text { Reserves (Ten } \\
\text { Thousand tons) }\end{array}$ & $\begin{array}{c}\text { Coal Seam } \\
\left.\text { Dip Angle ( }{ }^{\circ}\right)\end{array}$ \\
\hline $\begin{array}{l}\text { The west } \\
\text { wing stripe }\end{array}$ & $520 \sim 544$ & 3.29 & 1694 & 90 & 120 & 69.8 & 14 \\
\hline 1302 & $580 \sim 604$ & 3.29 & 1710 & 90 & 120 & 70.4 & 14 \\
\hline 1304 & $640 \sim 664$ & 3.29 & 1565 & 90 & 120 & 64.5 & 14 \\
\hline 1306 & $700 \sim 724$ & 3.29 & 1279 & 90 & 120 & 52.7 & 14 \\
\hline 1308 & $760 \sim 784$ & 3.29 & 980 & 90 & 120 & 40.4 & 14 \\
\hline 1301 & $560 \sim 585$ & 3.29 & 922 & 90 & 120 & 37.8 & 13 \\
\hline 1303 & $622 \sim 647$ & 3.29 & 572 & 90 & 120 & 23.5 & 13 \\
\hline 1305 & $685 \sim 710$ & 3.29 & 292 & 90 & 120 & 12.0 & 13 \\
\hline Total & $\backslash$ & $\backslash$ & 9014 & 720 & 960 & 371.1 & $\backslash$ \\
\hline
\end{tabular}

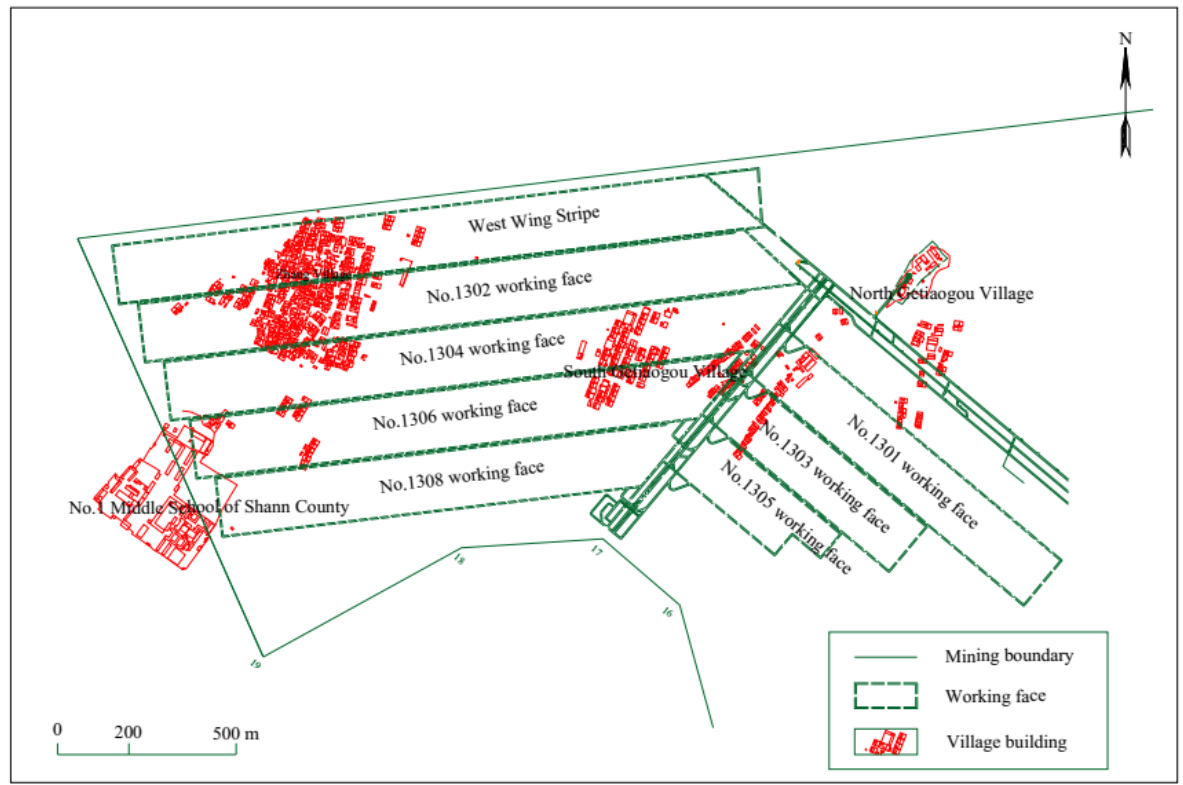

Figure 10. Panels layout diagram of scenario 2.

The main technical parameters of each mining panel are shown in Table 2 below. 
Table 2. Main technical parameters of each panel of in scenario 2.

\begin{tabular}{|c|c|c|c|c|c|c|}
\hline Panels & $\underset{(\mathrm{m})}{\text { Mining Depth }}$ & $\begin{array}{l}\text { The Average } \\
\text { Mining Thickness } \\
(\mathrm{m})\end{array}$ & $\begin{array}{l}\text { Panel Length } \\
\text { (m) }\end{array}$ & $\underset{\text { (m) }}{\text { Mining Width }}$ & $\begin{array}{l}\text { Reserves (Ten } \\
\text { Thousand tons) }\end{array}$ & $\begin{array}{c}\text { Coal Seam } \\
\text { Dip Angle }\left({ }^{\circ}\right)\end{array}$ \\
\hline $\begin{array}{l}\text { The west wing } \\
\text { stripe }\end{array}$ & $520 \sim 544$ & 3.29 & 1800 & 170 & 141.3 & 16 \\
\hline 1301 & $580 \sim 604$ & 3.29 & 922 & 170 & 71.4 & 13 \\
\hline 1302 & $640 \sim 664$ & 3.29 & 1750 & 170 & 136.8 & 15 \\
\hline 1303 & $700 \sim 724$ & 3.29 & 573 & 170 & 44.4 & 13 \\
\hline 1304 & $760 \sim 784$ & 3.29 & 1676 & 170 & 132.3 & 17 \\
\hline 1306 & $560 \sim 585$ & 3.29 & 1438 & 170 & 111.4 & 13 \\
\hline 1305 & $622 \sim 647$ & 3.29 & 401 & 170 & 31.2 & 14 \\
\hline 1308 & $685 \sim 710$ & 3.29 & 1204 & 170 & 94.1 & 15 \\
\hline Total & $\backslash$ & $\backslash$ & 9764 & 1360 & 762.9 & $\backslash$ \\
\hline
\end{tabular}

\section{Results and Discussion}

\subsection{PIM Prediction Outputs}

The PIM was adopted to calculate the surface displacement and deformation. The predicted parameters of strip mining were calculated by superposition of multiple strip working faces-that is, each strip panel (narrow and longwall working faces) was taken as the calculation area, respectively. The panel size of each strip is small due to the condition of subcritical extraction. The relation between the ultrasoft subcritical extraction parameters and the corresponding condition parameters of full subsidence was adopted to modify the parameters. Based on the time-series in situ monitoring data of the ground displacement of panel 1208 adjacent to the study area, the predicted parameters were retrieved. The program based on a genetic algorithm (GA) was used for parameter inversion, and the mining subsidence prediction (MSP) software developed by our research group was used for parameter inversion. The panel and the parameter setting file of GA are: the population size is 100 , iterations are 100 , cycle criterion 1 , crossover probability is 0.4 , and mutation probability is 0.001 . The estimated mining subsidence parameters of the strip mining scheme and fully mechanized coal winning in the study area are as shown in Table 3.

Table 3. Prediction parameters of PIM.

\begin{tabular}{cccccc}
\hline $\begin{array}{c}\text { Predicting } \\
\text { Parameters }\end{array}$ & Subsidence Factor $\boldsymbol{q}$ & $\begin{array}{c}\text { Displacement } \\
\text { Factor } \boldsymbol{b}\end{array}$ & $\begin{array}{c}\text { Tangent of Major } \\
\text { Influence Angle } \tan \boldsymbol{\beta}\end{array}$ & $\begin{array}{c}\text { Deviation of } \\
\text { Influencing Point } \boldsymbol{S}\end{array}$ & Propagation Angle $\boldsymbol{\theta}$ \\
\hline Scenario 1 & 0.2 & 0.3 & 1.9 & 0 & $88^{\circ}$ \\
Scenario 2 & 0.75 & 0.3 & 1.9 & 0 & $88^{\circ}$ \\
\hline
\end{tabular}

Scenario 1 , combined with the $K_{c}$ greater than 1.5 , meets the long-term support stability requirements of the Pssyst. Considering the features of ultrasoft strata, the safety factor of the coal pillar should be more than 2.0 in SMT. According to the data of the designed strip mining width, maximum mining depth and minimum mining depth, and approximate average unit weight of overlying strata, the $K_{c}$ was calculated as 2.19 , which can meet the long-term stability requirement of Pssyst. The predicted maximum surface displacement and deformation in the main building complex were calculated by PIM. The contour map of the mining subsidence, tilting, horizontal movement, and deformation of scenario 1 as shown in Figure 11a-g.

In scenario 1, the maximum subsidence after strip mining is $501 \mathrm{~mm}$ in the study area and $450 \mathrm{~mm}$ in the building complex. The maximum tilting in the south to north direction was about $1.7 \mathrm{~mm} / \mathrm{m}$, and $1.5 \mathrm{~mm} / \mathrm{m}$ in east to west direction; the maximum horizontal tensile deformation from south to north direction was $0.8 \mathrm{~mm} / \mathrm{m}$, and the maximum horizontal compression deformation was $1.4 \mathrm{~mm} / \mathrm{m}$; in the east to west direction, the maximum tensile and compression were 0.7 and $1.1 \mathrm{~mm} / \mathrm{m}$, respectively; the maximum horizontal movement of the surface from south to north was $154 \mathrm{~mm}$, and from east to west this was $153 \mathrm{~mm}$. 


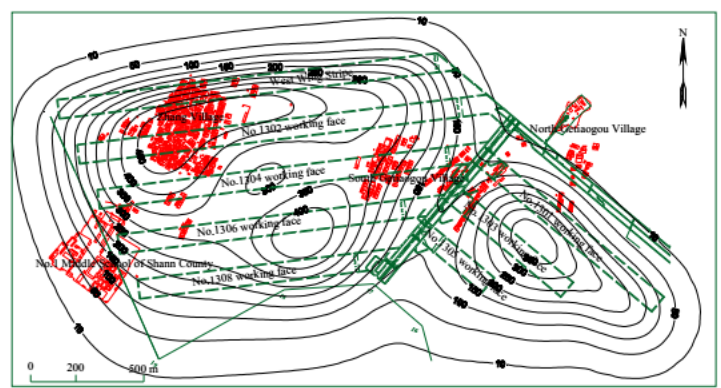

(a) Contour map of surface subsidence

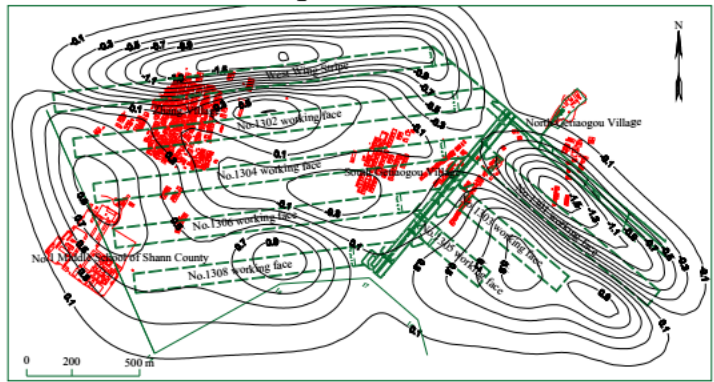

(c) Contour map of surface tilt (E-W)

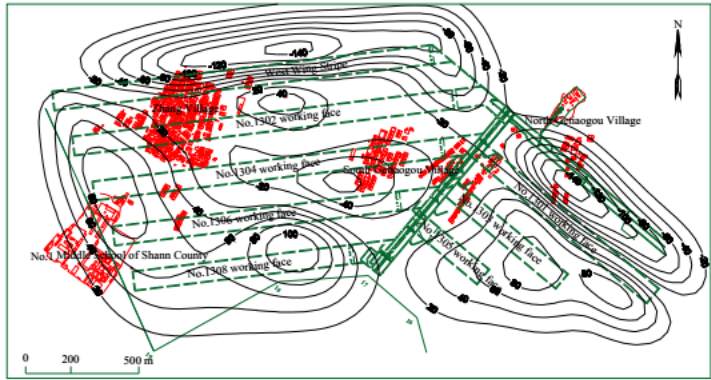

(e) Contour map of horizontal movement (E-W)

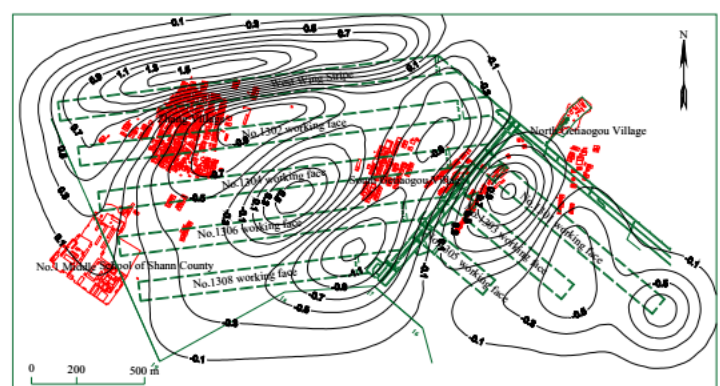

(b) Contour map of surface tilt (N-S)

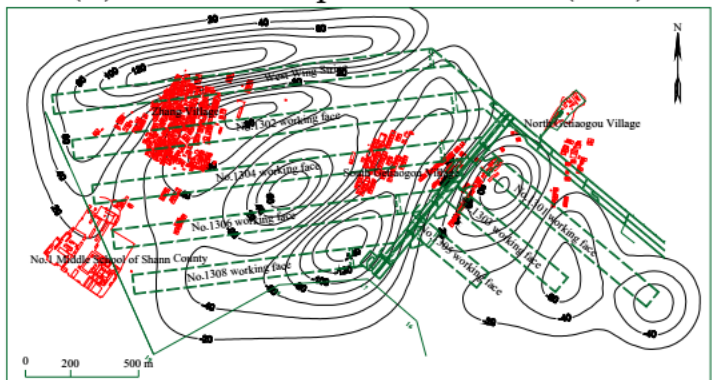

(d) Contour map of horizontal movement (N-S)

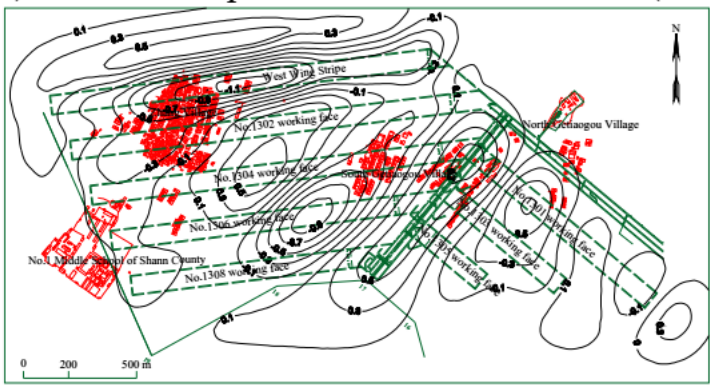

(f) Contour map of horizontal deformation (N-S)

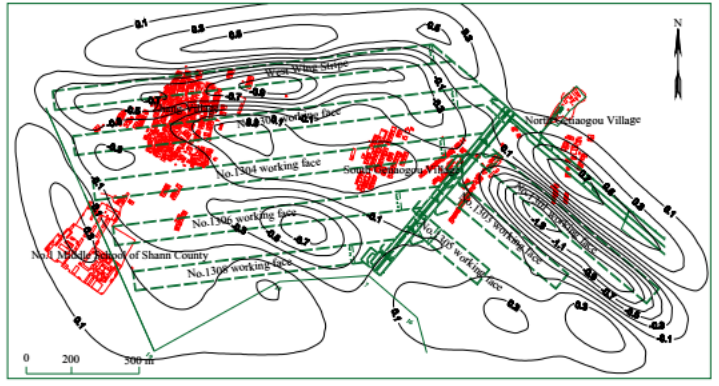

(g) Contour map of horizontal deformation (E-W)

Figure 11. Contour map of surface subsidence and deformation in scenario 1.

The contour map of the mining subsidence, tilting horizontal movement, and deformation of scenario 2, as shown in Figure 12a-g.

In scenario 2, the maximum subsidence after strip mining was $3534 \mathrm{~mm}$. The maximum tilting in the south to north direction was about $9.7 \mathrm{~mm} / \mathrm{m}$, and $10.4 \mathrm{~mm} / \mathrm{m}$ from east to west; the maximum tensile deformation from south to north was $4.4 \mathrm{~mm} / \mathrm{m}$, the maximum surface compression deformation was $7.3 \mathrm{~mm} / \mathrm{m}$; in the direction from east to west, the maximum tensile deformation and compression were $5.1 \mathrm{~mm} / \mathrm{m}$ and $7.8 \mathrm{~mm} / \mathrm{m}$, respectively; the maximum horizontal movement of the surface from south to north was $895 \mathrm{~mm}$, and from east to west this was $1127 \mathrm{~mm}$. 


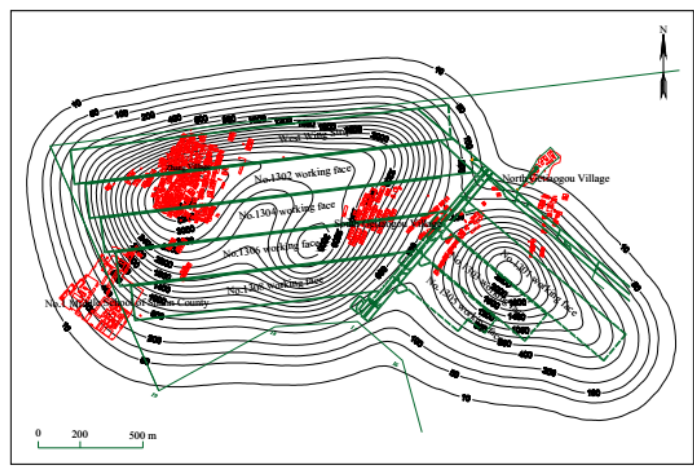

(a) Contour map of surface subsidence

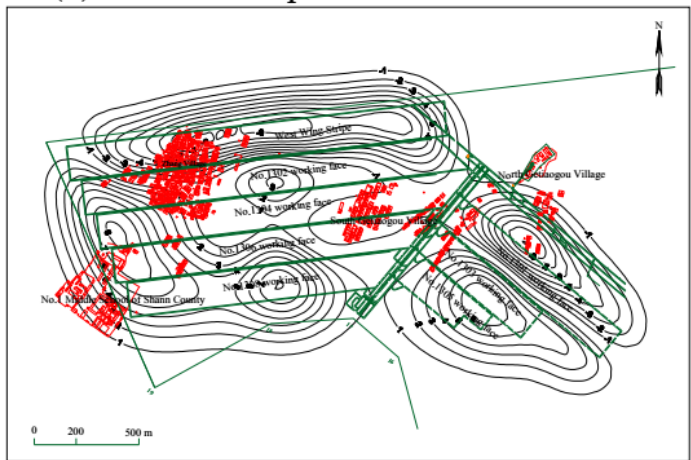

(c) Contour map of surface tilt (E-W)

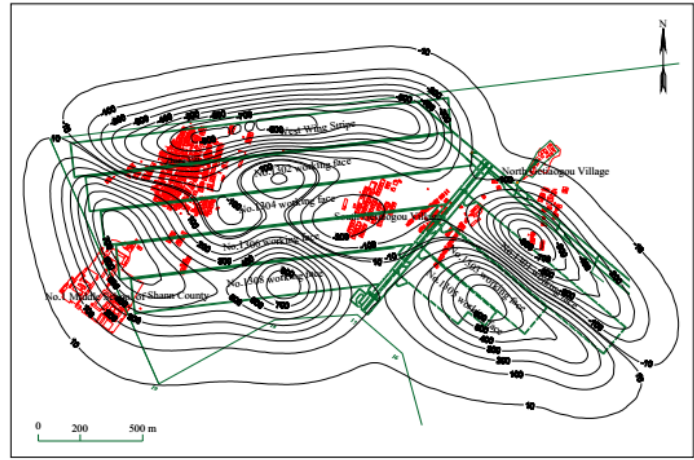

(e) Contour map of horizontal movement (E-W)

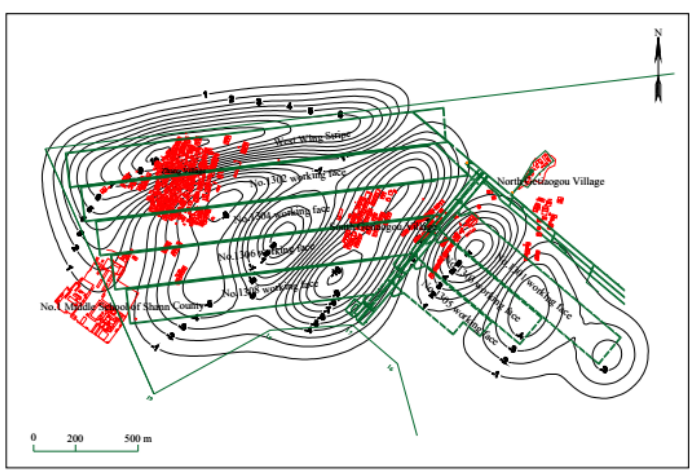

(b) Contour map of surface tilt (N-S)

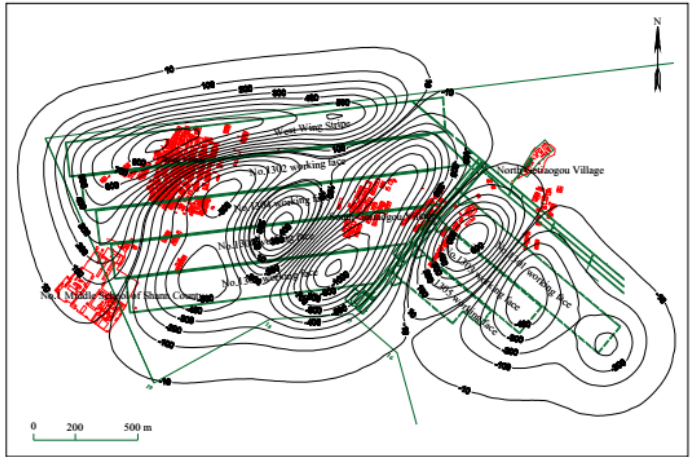

(d) Contour map of horizontal movement (N-S)

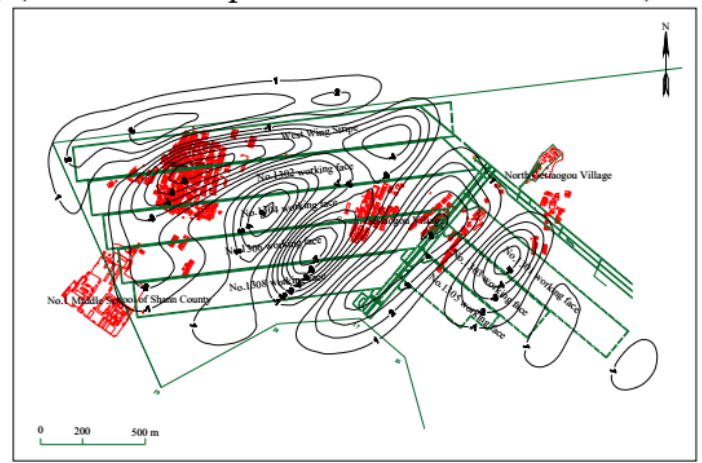

(f) Contour map of horizontal deformation (N-S)

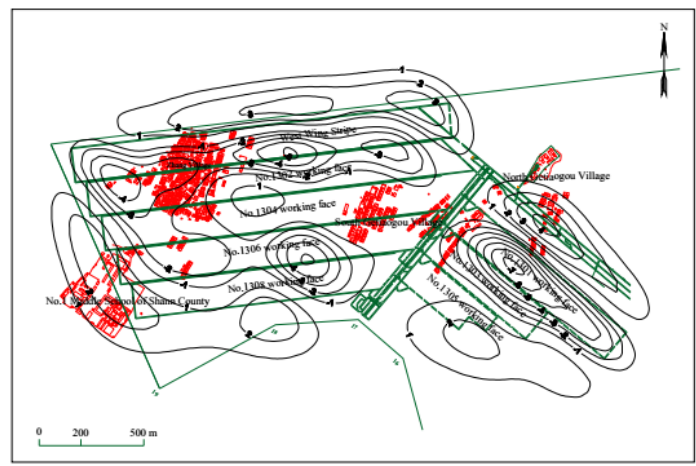

(g) Contour map of horizontal deformation (E-W)

Figure 12. Contour map of surface subsidence and deformation in scenario 2.

The PSsyst consists of in situ monitoring data and using PIM to predict the surface displacement and deformation comprehensively confirmed that the maximum surface subsidence predicted by PIM in scenario 2 is greater than that simulated by statistical modeling in scenario 1 . The results of the surface subsidence induced by strip mining 
are uniform, and the maximum surface subsidence was $501 \mathrm{~mm}$, while the maximum subsidence value predicted by the PIM was $3534 \mathrm{~mm}$, with a difference of $3033 \mathrm{~mm}$ in scenario 1. There is no wave subsidence on the surface, and the range of surface movement using the PIM is significantly smaller than the range of surface displacement and deformation in scenario 2.

To calculate the mining-induced damaged area caused by mining, a contour map of the damage level was drawn based on the moving deformation value of scenario 1, as shown in Figure 13a, and the determination of the damage scope was based on the Regulations of coal mining under buildings, water bodies, railway, and safety pillar design [37]. From Figure $13 b$, the damage caused by the fully mechanized coal winning technology is much more serious in scenario 2 , with the new collapse of residential land being about $3.883 \mathrm{~km}^{2}$. A protection rate of the residential area in the expected postmining area can reach as much as $6.91 \%$.

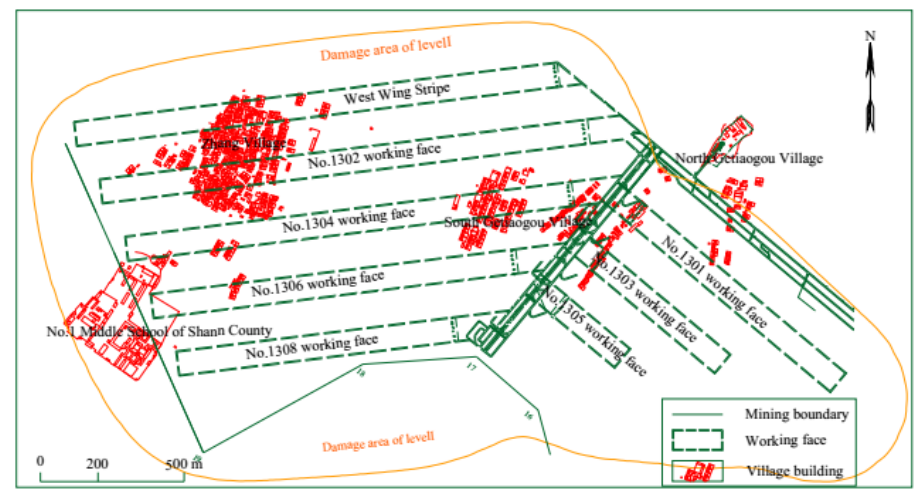

(a) scenario 1

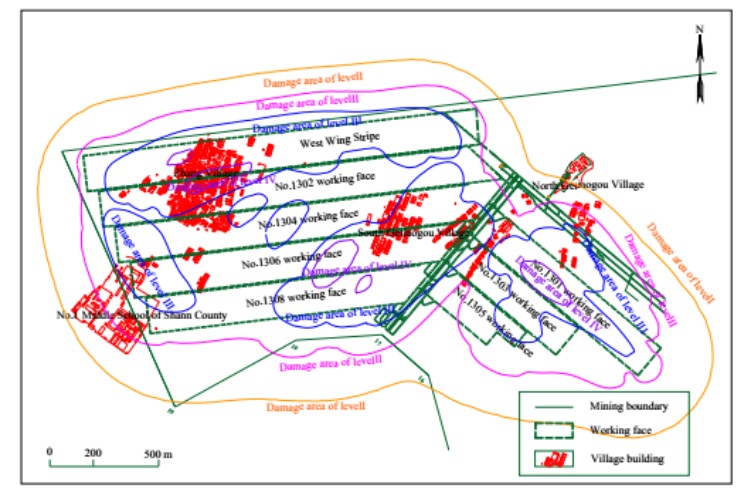

(b) scenario 2

Figure 13. Rating system of mining damage to ground building complex.

With a pillar width of $120 \mathrm{~m}$, cases of scenario 1 building complex damage degree are less than level I, with no more than 1 2 mm wide cracks appearing in the brick walls, which is very slight damage. The PSsyst to control the surface subsidence and damage is effective.

It was confirmed that the collaboration of PSsyst and PIM is expected to evaluate the feasibility of the mining surface displacement and deformation. The influence of strip mining on the surface mainly depends on whether there is a wave subsidence basin, which depends on the mining depth and the width of mining and retention, as well as the structure of overburden rock. The bigger the distance from the mining coal seam, the smaller the influence is. From the comprehensive predicted results, it can be seen that there is no wave subsidence basin on the surface in scenario 1 because the mining depth is relatively deep and the determination of the pillar width is reasonable. Meanwhile, the PIM is a statistical method and has the shortcoming of too fast convergence in the boundary, so the error of the method in predicting the mining boundary is large. This can be seen from the comparison of the two mining scenarios. However, pillar retention is considered from the point of view of safety, and the building complex was not affected by significant mining activity.

\subsection{Economic Evaluation}

On the other hand, from an economic point of view, the feasibility of coupling building protection with SMT in the ultrasoft colliery should be analyzed. In total, 3.711 million tons of raw coal can be producted under scenario 1, and 7.629 million tons of coal can be produced under scenario 2 . 


\subsubsection{Estimation of Coal Mining Profits}

According to the actual operation of the colliery, the production cost of coal in 2020 is about CNY 280 per ton, and the average selling price of coal is about CNY 430 (excluding tax). The economic profit of coal is CNY 150 per ton. Then, it was approximately estimated that the coal mining profit obtained by each scenario is as follows:

Scenario 1: the coal mining profit is CNY 150 per ton $\times 3.711$ million tons $=\mathrm{CNY}$ 556.65 million;

Scenario 2: the coal mining profit can be CNY 150 per ton $\times 7.629$ million tons $=\mathrm{CNY}$ 1144.35 million.

\subsubsection{Estimation of Maintenance Compensation Cost and Profit in Scenario 1}

Within the scope of the mining areas, except for North Getiaogou village, which is located in the mining damage area with a total area of $5289 \mathrm{~m}^{2}$, the compensation for level I mining-induced damage buildings was temporarily estimated according to the brick-concrete structure standard of CNY $250 / \mathrm{m}^{2}$ according to the compensation experience of local mining enterprises in recent years. The estimated compensation costs are $215,359 \mathrm{~m}^{2} \times \mathrm{CNY} 250 / \mathrm{m}^{2}=\mathrm{CNY} 53.83$ million. Considering the $15 \%$ unforeseeable fee, the total compensation cost is CNY 61.92 million. After deducting the ground building maintenance compensation costs, the total profit obtained by applying scenario 1 is CNY 494.73 million.

\subsubsection{Estimation of Village Relocation Costs and Profits for Scenario 2}

From the surface moving and deformation contour map after mining under scenario 2, the buildings in Zhang village, South Getiaogou Village, and most areas of North Getiaogou Village and No.1 middle school of Shaan County above the mining area will be damaged at level III by underground extraction; other affected village buildings are mainly affected by level I to level II mining damage.

In the mining-induced relocation of the coal village, the colliery may pay the relocation compensation fee based on the registered building area. The relocation expense mainly consists of the land acquisition fee of the new village, residential relocation fee, relocation, road repair fee, and backfilling earthwork fee. Combined with the actual situation in this area, the comprehensive relocation cost of compressed coal village is equivalent to about CNY 300,000 per household. It was estimated that a total of 368 households and 1398 people will need to be relocated at Zhang village, South Getiaogou village, etc. The estimated total relocation cost: CNY 300,000/household $\times 368$ households $=$ CNY 110.4 million. After deducting the relocation expense of surface villages, the total profit obtained by adopting the fully mechanized coal winning technology in scenario 2 is as follows: CNY 1.1444 billion - CNY 110.4 million = CNY 1.034 billion .

Additionally, considering that the buildings of the No.1 middle school sites in Shaan County are temporarily out of utilization, the damage caused by mining can be directly compensated with monetary compensation. Considering the selling price of local commercial housing, the compensation shall be temporarily based on CNY $1000 / \mathrm{m}^{2}$. The expected compensation is $52,190 \mathrm{~m}^{2} \times \mathrm{CNY} 1000 / \mathrm{m}^{2}=\mathrm{CNY} 52.19$ million. In addition, for the above villages and the old site buildings, compensation will be paid to the four villages of North Getiaogou village. The compensation for the damage to the building by level I and level II will be temporarily implemented according to the standard of brick-concrete structure of CNY $250 / \mathrm{m}^{2}$. The estimated compensation costs are $36,490 \mathrm{~m}^{2} \times$ CNY $250 / \mathrm{m}^{2}=$ CNY 9.12 million.

To sum up, according to the fully mechanized coal winning technology in scenario 2, the final net profit is CNY 972.64 million. 


\subsubsection{Scenario Comparison}

By referring to the calculation of the above costs and based on the input and output that the mining scenario may bring, approximate estimates of economic benefits and possible social problems of different scenarios are presented in Table 4.

Table 4. Comparison of economic benefits of two scenarios under building complex.

\begin{tabular}{cccccc}
\hline Mining Scheme & $\begin{array}{c}\text { Building } \\
\text { Treatment Scheme }\end{array}$ & $\begin{array}{c}\text { Recoverable Coal } \\
\text { Quantity } \\
\text { (Million tons) }\end{array}$ & $\begin{array}{c}\text { Coal Mining Profits } \\
\text { (Million CNY) }\end{array}$ & $\begin{array}{c}\text { Cost of Villages } \\
\text { (Million CNY) }\end{array}$ & $\begin{array}{c}\text { Economic Benefit } \\
\text { (Million CNY) }\end{array}$ \\
\hline Scenario 1 & $\begin{array}{c}\text { Maintenance } \\
\text { compensation }\end{array}$ & 3.711 & 556.65 & 61.92 & 494.73 \\
\hline Scenario 2 & Overall relocation & 7.629 & 1144.35 & 171.71 & 972.64 \\
\hline
\end{tabular}

From Table 4, the economic benefits of scenario 1 are poor due to a large amount of coal loss. After mining according to scenario 2, the collapse method will bring great economic benefits, but it may lead to disputes between workers and farmers and forced relocation. From an economic point of view, the coal resources beneath the buildings, if not mining, will be a waste of resources. In an ultrasoft coal mine, fully mechanized mining surface damage is more serious. From the perspective of the environment, the mining of large areas by the caving method results in serious surface subsidence, which is expected to cause serious damage when it affects village buildings. Overall, PSsyst can effectively reduce mining subsidence in the ultrasoft strata colliery and maintain the sustainable exploitation of natural resources and the sustainable development of human beings.

\section{Conclusions}

This study conducted a technical and economic feasibility study of the pillar-support system design of the reservation width of the strip mining technology underneath a building complex. The research results demonstrated that PSsyst has good economic and environmental benefits. The statistical model results show that the subsidence basin formed on the surface after strip mining is relatively gentle, surface deformation is very slight, there was no wavy subsidence, and it has a certain guiding role in optimizing strip pillar design. Based on the 2020 coal price index, the total benefits of the projects are CNY 494.73 million and CNY 972.64 million, with a pillar width of $120 \mathrm{~m}$, mining width of $90 \mathrm{~m}$ (scenario 1), and mining width of $170 \mathrm{~m}$ (scenario 2), respectively. The contour map of mining-induced damage further revealed that the average cultivated land that was protected was $6.91 \%$ compared to the fully mechanized coal winning technology from scenario 2 . Furthermore, PSsyst has significant effects on extending the mining life of the colliery and excellent performance with regard to sustainable development from economic and environmental perspectives. The PSsyst can further reduce the scope of ground subsidence and the difficulty of subsequent comprehensive treatment of coal mining subsidence. It is of great significance to the protection of cultivated land resources, the improvement of ecological environment, the expansion of urban development space, and the harmony and stability of society.

However, some possible issues require further consideration regarding, for instance, the protective coal pillar left by the PSsyst requiring great technical requirements in the secondary recovery and groundwater recovery in closed mines leading to instability in the PSsyst and possibly influencing the water ecosystem. As we predicted, when the PSsyst was immersed in underground water for a long time, it underwent softening and creeping, and the strength of the coal pillar gradually decreased, which led to the descent of the core area of the PSsyst and the reduction in its stability, and the support effect was bound to decline-this will also be the focus of our future work. 
Author Contributions: Conceptualization, G.G. and S.G.; Methodology, S.G.; Analysis, S.G.; Investigation, Q.D. and S.G.; Resources, X.Y.; Writing-Original draft preparation, S.G.; Writing-Review and editing, Q.D.; Supervision, G.G.; Project administration, G.G.; Funding acquisition, G.G. All authors have read and agreed to the published version of the manuscript.

Funding: This research was supported by the National Natural Science Foundation of China (Grant No. 51974292) and also supported by Fundamental Research Funds for the Central Universities (Grant No. 2018ZDPY05).

\section{Institutional Review Board Statement: Not applicable \\ Informed Consent Statement: Not applicable}

Acknowledgments: The authors would like to express their sincere gratitude to the Sanmenxia Longwangzhuang Coal Industry Co. LTD of Henan Energy and Chemical Industry Group for their data support. In addition, the authors are grateful to the assigned editor and the anonymous reviewers for their enthusiastic help and valuable comments, which have greatly improved this paper.

Conflicts of Interest: The authors declare no conflict of interest.

\section{References}

1. Guo, G.L.; Feng, W.K.; Zha, J.F. Subsidence control and farmland conservation by solid backfilling mining technology. Trans. Nonferrous Met. Soc. China 2011, 21, 665-669. [CrossRef]

2. Zhu, W.; Xu, J.; Chen, D.; Shi, J. Pier-column backfill mining technology for controlling surface subsidence. Int. J. Rock Mech. Min. Sci. 2017, 96, 58-65. [CrossRef]

3. Kivinen, S. Sustainable Post-Mining Land Use: Are Closed Metal Mines Abandoned or Re-Used Space? Sustainability 2017, 9 , 1705. [CrossRef]

4. Liu, G.; Xu, N.Z. Mining design under villages and comparison analysis of mining method. Coal Min. Technol. 2015, 127, 87-89. (In Chinese) [CrossRef]

5. Li, J.; Zhang, Z.W.; Yang, Y. Program design and application of strip mining of Xima coal mine under the village. Saf. Coal Mines 2017, 48, 155-158. (In Chinese)

6. Deng, W.; Zhang, H. Methods for safety mining of protective coal pillar under a highway in China. Int. Conf. Remote Sens. Environm. Transp. Eng. 2011, 4166-4168.

7. Zhu, X.J.; Guo, G.L.; Liu, H.; Peng, X.N.; Yang, X.Y. Research on the stability evaluation model of composite support pillar in backfill-strip mining. Math. Probl. Eng. 2020, 2020, 3138258. [CrossRef]

8. Wang, R.; Bai, J.B.; Yan, S.; Chang, Z.G.; Yang, X.Y. An innovative approach to the theoretical analysis of partitioned width \& stability of strip pillar in strip mining. Int. J. Rock Mechan. Min. Sci. 2020, 129, 1-13.

9. Zhang, W.Q.; Liu, H.L.; Zhao, K. Influential factors on surface subsidence in stripe mining under thick unconsolidated layers and thin bedrock. J. Min. Safety Eng. 2016, 33, 1065-1071.

10. Didier, C. Postmining management in France: Situation and perspectives. Risk Anal. 2010, 29, 1347-1354. [CrossRef]

11. Ilia, I.; Loupasakis, C.; Tsangaratos, P. Land subsidence phenomena investigated by spatiotemporal analysis of groundwater resources, remote sensing techniques, and random forest method: The case of Western Thessaly, Greece. Environ. Monit. Assess. 2018, 190, 11-19. [CrossRef] [PubMed]

12. Malkowski, P.; Niedbalski, Z.; Majcherczyk, T. Roadway design efficiency indices for hard coal mines. Acta Geodyn. Geomater. 2016, 13, 201-211. [CrossRef]

13. Li, C.Y.; Cui, X.M.; Hu, Q.F.; He, R. An analysis of extra-thick coal mining influence on ground surface deformation under the condition of the massive conglomerate stratum in Changcun colliery. J. Min. Safety Eng. 2015, 32, 628-633.

14. Zou, Y.F.; Chai, H.B. Research status of strip coal pillar stability and its main problems in China. J. Min. Safety Eng. 2006, 23, 141-145, 150. (In Chinese)

15. Guo, G.L.; Deng, K.Z.; Chang, J. Study on the foundation settlement of heavy buildings above mine gobs. J. China Univ. Min. Technol. 1996, 12, 54-57. (In Chinese)

16. Ning, J.; Wang, J.; Tan, Y.; Zhang, L.; Bu, T. In situ investigations into mining-induced overburden failures in close multiple-seam longwall mining: A case study. Geomech. Eng. 2017, 12, 657-673. [CrossRef]

17. Hamdi, P.; Stead, D.; Elmo, D.; Toyra, J. Use of an integrated finite/discrete element method-discrete fracture network approach to characterize surface subsidence associated with sub-level caving. Int. J. Rock Mech. Min. Sci. 2018, 103, 55-67. [CrossRef]

18. Salmi, E.F.; Nazem, M.; Karakus, M. Numerical analysis of a large landslide induced by coal mining subsidence. Eng. Geol. 2017, 217, 141-152. [CrossRef]

19. Corkum, A.G.; Board, M.P. Numerical analysis of longwall mining layout for a Wyoming Trona mine. Int. J. Rock Mech. Min. Sci. 2016, 89, 94-108. [CrossRef]

20. Ghabraie, B.; Ren, G.; Smith, J.V. Characterizing the multi-seam subsidence due to varying mining configuration, insights from physical modeling. Int. J. Rock Mech. Min. Sci. 2017, 93, 269-279. [CrossRef] 
21. Rezaei, M.; Hossaini, M.F.; Majdi, A. Determination of Longwall Mining-Induced Stress Using the Strain Energy Method. Rock Mech. Rock Eng. 2015, 48, 2421-2433. [CrossRef]

22. Alam, M.S.; Kumar, D.; Chatterjee, R.S.; Upreti, V. Assessment of Land Surface Subsidence Due to Underground Metal Mining Using Integrated Spaceborne Repeat-Pass Differential Interferometric Synthetic Aperture Radar (D-InSAR) Technique and Ground Based Observations. J. Indian Soc. Remote Sens. 2018, 46, 1569-1580. [CrossRef]

23. Swift, G. Relationship between joint movement and mining subsidence. Bull. Eng. Geol. Environ. 2014, 73, 163-176. [CrossRef]

24. Yang, K.; Gou, P.F. Research on Reasonable width of coal pillars in high strength mining roadway in Wantugou mine. Geotech. Geol. Eng. 2020, 16, 1-9. [CrossRef]

25. Li, H.Z.; Zha, J.F.; Guo, G.L.; Zheng, N.S.; Gong, Y.Q. Improvement of resource recovery rate for underground coal gasification through the gasifier size management. J. Clean. Prod. 2020, 259, 12-20. [CrossRef]

26. Sanmiquel, L.; Bascompta, M.; Vintro, C.; Yubero, T. Subsidence Management System for Underground Mining. Minerals 2018, 8, 243. [CrossRef]

27. Li, D.H. The rule of surface movement in strip mining of three soft thick coal seams. Mine Surv. 1997, 1, 8-11. (In Chinese)

28. Wang, L.; Wei, T.; Li, N. Research on probability integration parameter inversion of mining-induced surface subsidence based on quantum annealing. Environ. Earth Sci. 2018, 77, 1-13. [CrossRef]

29. Zha, J.F.; Guo, G.L.; Zhao, H.T.; Jia, X.G. Present situation and the prospect of correction system for probability integral method. Metal Mine 2008, 1, 15-18. (In Chinese)

30. Hao, C.B.; Zhao, R.X. Numerical simulation and strip mining design under the building of one village. Coal Min. Technol. 2017, 22, 55-58. (In Chinese)

31. Li, P.X.; Tan, Z.X.; Wang, L. Evaluation on the stability of building foundation over old-goaf with FLAC. Coal Saf. 2009, 10, 11-14. (In Chinese)

32. He, R.; Guo, Z.Z.; Chen, J.J. Research on methods of mining width determination in deep trip pillar mining. J. Henan Polytec. Univ. 2009, 28, 155-159. (In Chinese)

33. Luan, Y.Z.; Dong, Y.; Ma, Y.H.; Weng, L.Y. Surface and new building deformation analysis of deep well strip mining. Adv. Mater. Sci. Eng. 2020. [CrossRef]

34. Salmi, E.F.; Nazem, M.; Karakus, M. The effect of rock mass gradual deterioration on the mechanism of post-mining subsidence over shallow abandoned coal mines. Int. J. Rock Mech. Min. Sci. 2017, 91, 59-71. [CrossRef]

35. Cui, X.M.; Deng, K.Z. Research review of predicting theory and method for coal mining subsidence. Coal Sci. Technol. 2017, 45, 160-169. (In Chinese)

36. Cui, X.; Zhao, Y.; Wang, G.; Zhang, B.; Li, C. Calculation of residual surface subsidence above abandoned longwall coal mining. Sustainability 2020, 12, 1528. [CrossRef]

37. State Administration of Work Safety; National Coal Mining Safety Administration; National Energy Administration; National Railway Administration. Regulations of Coal Mining under Buildings, Water Bodies, Railway and Safety Pillar Design; Coal Industry Press: Beijing, China, 2017. (In Chinese) 